\title{
Tough, Rugged, and Evolving Masculinity: Harry Compton, an Enslaved and Free Black Man in Eighteenth-and Early \\ Nineteenth-Century New Jersey \\ By Kenneth E. Marshall
}

DOI: https://doi.org/10.14713/njs.v7i1.226

This article explores the little known yet intriguing life of Harry Compton (c. 1743-c. 1814), who first comes to our attention in the 1883 narrative of the life of his famed granddaughter, Silvia Dubois. An enslaved person turned independent businessman, Compton constructed a complex and evolving concept of masculinity in the face of oppression, encouraging us to understand black masculinity in slavery and freedom as a life-long pursuit of self-empowerment and personal reinvention. His story, which occurred mostly in rural New Jersey, adds nuance to scholars' understanding of black masculinity as a public performance that showcased one's power and authority, or self-worth, while also providing an important example of black masculinity as a developing process. In telling Compton's story, the article advances a number of narrative threads pertaining to eighteenth- and early nineteenth-century New Jersey, including slavery, gender, culture and economy, and the law. An analysis of Compton allows the reader to learn a great deal about the world in which he lived and, ultimately, overcame through his dynamic masculinity performed in various public settings.

\section{Introduction}

In the foreword to Silvia Dubois, A Biografy of the Slav Who Whipt Her Mistres and Gand Her Fredom, published in 1883, author Cornelius Larison (1837-1910) introduces his readers to his titular heroine's maternal grandfather, a local New Jersey legend in his own right. "Harry Put had an instinctive desire to be free," remarks Larison. "Being industrious, frugal, and honorable, 
he managed to buy his time of his master, Richard Compton. Charcoal being much in demand in those times, he turned his attention to the burning of coalpits and at the business accumulated a little money. With his earnings, he purchased a site and erected a house. His social qualities, and the supply of liquor always on hand, made his house a popular place of resort." ${ }^{1}$ In her narrative, Silvia Dubois (c. 1788/89-1888) confirms her grandfather's masculine prowess, boasting that, "he was considered the best dancer on the [Sourland] mountain, or that has ever been on this mountain, or anywhere in these parts. I have seen him when he was old, dance at Princeton, and everybody who saw him said that he was the best dancer they ever saw." Dubois continues, "he was short, but very stout, and very strong. He was considered the strongest man on the mountain, and they used to say he was the strongest Negro that ever lived, and he was very active. He could put any man upon the ground, white or black." 2

Harry Put, also known as Harry or Henry Compton (c. 1743-c. 1814), does not figure in the scholarly accounts of enslaved and free black men in eighteenth- and nineteenth-century America. ${ }^{3}$ And yet, as the comments above suggest, and as this article seeks to demonstrate, the

\footnotetext{
${ }^{1}$ C. W. Larison, Silvia Dubois, A Biografy of the Slav Who Whipt Her Mistres and Gand Her Fredom, ed. and trans. Jared C. Lobdell (New York: Oxford University Press, 1988 [1883]), 30. Lobdell normalizes the phonetic spelling of the original 1883 version of the Biografy, reprinted in its entirety at the end of the 1988 volume. Unless stated otherwise, the article uses the edited 1988 version of the Biografy. The narrative's phonetic spelling represents Larison's devotion to spelling reform. See Harry B. Weiss, Country Doctor: Cornelius Wilson Larison of Ringoes, Hunterdon County, New Jersey, 1837-1910; Physician, Farmer, Educator, Author, Editor, Publisher and Exponent of Phonetic Spelling (Trenton: New Jersey Agricultural Society, 1953), chap. 9.

${ }^{2}$ Larison, Biografy, 94.

${ }^{3}$ For Compton's death around 1814, see Will and Inventory of Henry Compton, no. 2648, New Jersey Department of State, Division of Archives and Records Management, Archives Section, Trenton (hereafter cited as NJSA). (The will was filed on January 21, 1813, and proved on May 5, 1814. The estate inventory was made on April 26, 1814.) The will and inventory refute Jared Lobdell's contention that "Harry was alive in 1830, dead by 1840" (Larison, Biografy, $85 \mathrm{n}$. 25). It remains far from clear, however, when Harry was actually born. We can guesstimate his year of birth by tracing it through his female family members. Lobdell makes a solid case for how Silvia Dubois was born around 1788/89 (4-12). If we assume that Silvia's mother and Harry's daughter, Dorcas Compton, was around age twenty when she gave birth to Silvia, then Dorcas was born around 1768 (11, 85 n. 25). And if Jude Compton, Harry's wife mentioned in his will, was about the same age when Dorcas was born, this places Jude's year of birth around 1748. Lastly, if we assume that Harry was slightly older than Jude, say by about five years, then he was born around 1743. In short, Harry possibly died around age seventy-one. While hardly definitive, this estimation sounds much more plausible than Silvia's assumption based on local legend that Harry lived past one hundred years (70). My thinking here reflects how a great many colonial American women married around age twenty and had children shortly
} 
unheralded Compton constructed a complex and evolving concept of masculinity in the face of oppression. Compton, who was a fighter, dancer, charcoal maker, and tavern owner, among other things, encourages us to understand black masculinity in slavery and freedom as a life-long pursuit of self-empowerment and personal reinvention. On the one hand, his story, which occurred mostly in rural New Jersey, adds nuance to scholars' understanding of black masculinity as a performance that showcased one's power and authority, or self-worth. Timothy Buckner, for example, notes that William Johnson (1809-51), an enslaved person turned prominent free black barber in preCivil War Natchez, Mississippi, "believed that there was a public component to being a man that required boldness and the willingness to take risks." For Johnson, who not only purchased land and became the landlord of white tenants over whom he had authority, but also competed against his friends, sons, and bondpeople in running and jumping, gambling, shooting targets, and betting on horse races, “manliness was competitive," Buckner emphasizes. ${ }^{4}$ Correspondingly, Jeff Forret, Sergio Lussana, and David Doddington show how bondmen in the antebellum South conceptualized masculinity as performance through various public mediums, including work, resistance, leisure pursuits, intraracial violence, and familial responsibility as providers and protectors. ${ }^{5}$ A focus on Compton provides a critical northern dimension lacking in the scholarship.

thereafter (keeping in mind, of course, that enslaved marriages were not legal). See Susan E. Klepp, Revolutionary Conceptions: Women, Fertility, and Family Limitation in America, 1760-1820 (Chapel Hill: University of North Carolina Press, Omohundro Institute of Early American History and Culture, 2009), 43.

${ }^{4}$ Timothy R. Buckner, "A Crucible of Masculinity: William Johnson's Barbershop and the Making of Free Black Men in the Antebellum South," in Fathers, Preachers, Rebels, Men: Black Masculinity in U.S. History and Literature, 1820-1945, ed. Buckner and Peter Caster (Columbus: Ohio State University Press, 2011), 43-51 ("believed that there was a public component" on 43, "manliness was competitive" on 51).

${ }^{5}$ Jeff Forret, Slave against Slave: Plantation Violence in the Old South (Baton Rouge: Louisiana State University Press, 2015), chap. 7; Sergio Lussana, My Brother Slaves: Friendship, Masculinity, and Resistance in the Antebellum South (Lexington: University Press of Kentucky, 2016), chaps. 1-3; David Stefan Doddington, Contesting Slave Masculinity in the Antebellum South (Cambridge: Cambridge University Press, 2018), chaps. 2-5. 


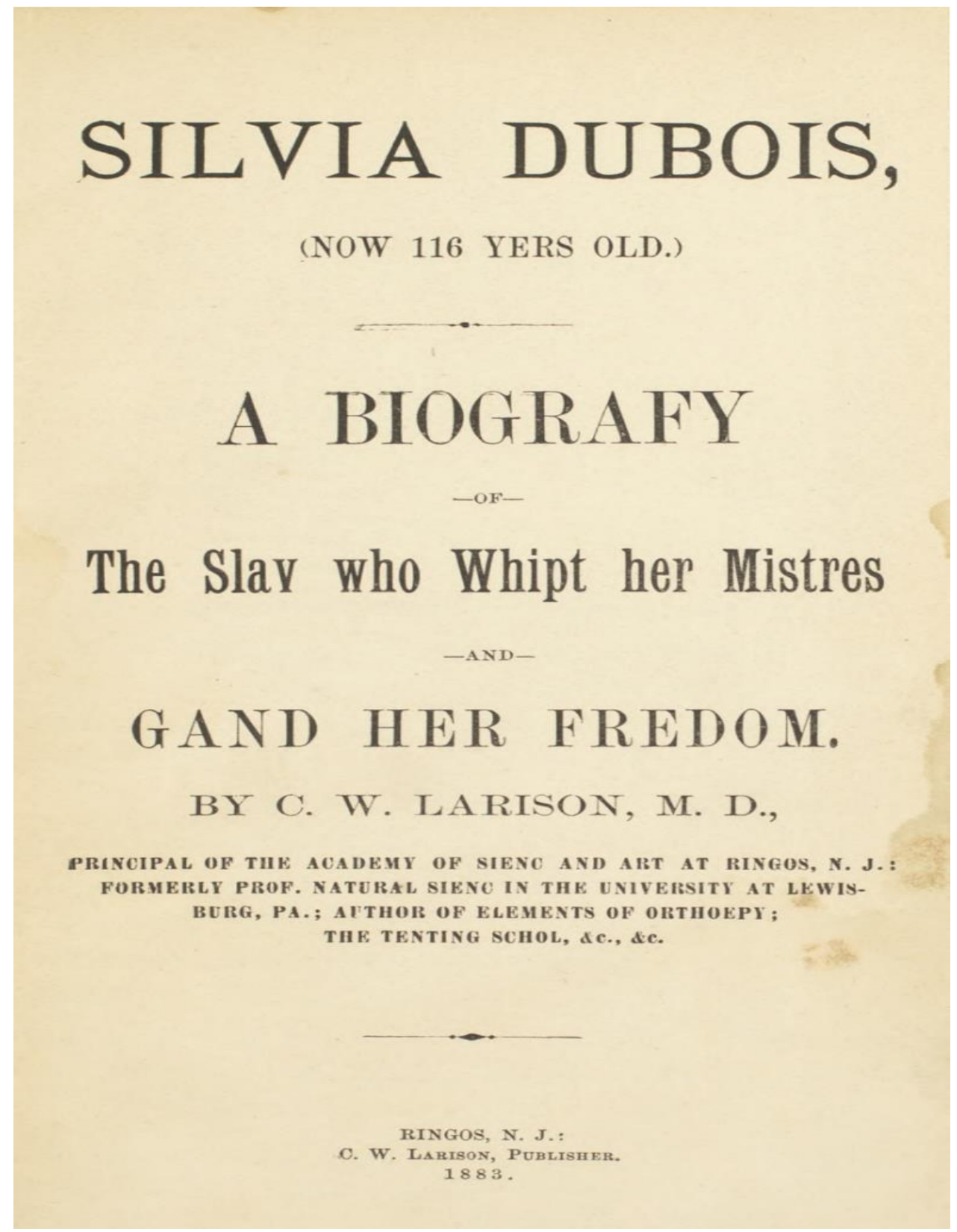

Title page of C. W. Larison's Silvia Dubois, A Biografy of the Slav Who Whipt Her Mistres and Gand Her Fredom (Ringoes, NJ: C. W. Larison, 1883). University of Michigan, https://babel.hathitrust.org/cgi/pt?id=mdp.69015000002713;view=1up;seq=7. Color version available as an online enhancement.

On the other hand, Compton's story reflects Doddington's recent call for scholars of enslaved men to begin considering "change over the course of a lifespan." Doddington argues that the aging of enslaved southern men compromised their masculine identity of strength and 
authority, and hence their status in the eyes of both their enslavers and fellow blacks. ${ }^{6}$ Compton chose not to construct his masculine identity strictly in terms of his physical prowess, appearing to have realized that it served his interests to do so in alternative ways that lent him authority and public visibility.

In what follows, this article draws on the experiences of certain family members of Compton, and those of other enslaved and free black men, to deepen understanding of how Compton crafted his masculinity. The piece also engages with the Biografy, the basis of Compton's story. While Larison applauds Compton for exerting discipline and determination to purchase his freedom, the author was not interested in Compton as a historical subject per se, but rather as a cautionary example of black freedom run amok. ${ }^{7}$ Thus important gaps about Compton's life - such as his role as a dedicated family man - appear in Larison's "brief sketch" about his rural mountain tavern of "ill fame" that Dubois operated after his death. ${ }^{8}$

This case study in black masculinity is structured in three parts. The first part places Compton in the context of the hostile and violent relationship between enslaved men and their male owners, and speculates that he used his owner's rural hotel and tavern to exhibit his physical dominance, which heightened his public visibility. The second part argues that the Revolutionary War inspired Compton to evolve in his masculine identity as a soldier and charcoal makerbusinessman who purchased his freedom and then migrated elsewhere to stake his claim over his life and body. The third and final part discusses how Compton's erection of Put's Tavern allowed him to occupy the "center" as he became his own "master." Put's Tavern, in other words,

\footnotetext{
${ }^{6}$ David Doddington, “'Old Fellows': Age, Identity, and Solidarity in Slave Communities of the Antebellum South," Journal of Global Slavery 3, no. 3 (2018): 286-312 (quote on 86).

${ }^{7}$ On Larison's racial conservatism, see Michael C. Berthold, “The peals of her terrific language': The Control of Representation in Silvia Dubois, a Biografy of the Slav Who Whipt Her Mistres and Gand Her Fredom," MELUS 20, no. 2 (1995): 12.

${ }^{8}$ Larison, Biografy, 27-34 (phrases on 27).
} 
represented the pinnacle of his evolving masculinity. As implied in this synopsis, Compton, in a novel way, reflects scholars' understanding of masculinity as socially constructed; he used his social environments to grow and transform as a man of worth. ${ }^{9}$ As also implied here, the article advances a number of narrative threads pertaining to eighteenth- and early nineteenth-century New Jersey, including slavery, gender, culture and economy, and the law. An analysis of Compton allows the reader to learn a great deal about the world in which he lived and, ultimately, overcame through his dynamic masculinity performed in various public settings. His story is worth being told.

\section{The Utility of Violence in a Hostile (Violent) World}

According to Cornelius Larison, "Harry [Compton] was a slave to General Rufus Putnam [?], who sold him to Captain Ryner Staats, who sold him to Richard Compton," a hotel and tavern owner; his enslavement took place mainly, if not exclusively, on Sourland Mountain in Hillsborough Township, Somerset County. ${ }^{10}$ Bondage in the rural environs of New York City, which included Somerset County, was characterized by small holdings (on average about two or three enslaved blacks per family), the frequent dispersal of blacks among white relatives, and the high turnover of enslavers, all of which proved detrimental to black family formation. ${ }^{11}$ Moreover,

\footnotetext{
9 See, for example, Michael S. Kimmel, Manhood in America: A Cultural History, 2d ed. (New York: Oxford University Press, 2006), 3.

${ }^{10}$ Larison, Biografy, 28 (quote), 53-54. Jared Lobdell questions Compton's connection to General Putnam: "I suspect 'mythic' remembering and that the Putnam involved was Seth Putnam of Somerset County - but perhaps not" (47 n. 2). In 1791, Seth Putman purchased land with Hillsborough Township resident Minna Dubois - former owner of Silvia Dubois and her mother, Dorcas Compton - in Great Bend, Pennsylvania (9-10, 22 n. 13, 52-53). Yet in support of Larison, an 1888 newspaper account of Silvia Dubois refers to Harry Compton as “General Rufus Putnam's bodyservant and afterward the noted colored fifer of the Continental army." See New York Tribune, April 29, 1888. To my mind, Compton's service under General Putnam as a short-term "body-servant" sounds much more plausible than as a long-term "slave," though, overall, his connection to Seth Putnam makes the most logical sense. Richard Cumpton (Compton) and Rynier (Ryner) Staats are listed, respectively, in "Hillsborough Township 'Census' of 1784," Somerset County Genealogical Quarterly 2, no. 2 (1984): 103; and ibid. 2, no. 3 (1984): 130. On General Putnam, who hailed from Massachusetts and served as a key military officer during the Revolutionary War, see Fred J. Milligan, Ohio's Founding Fathers (Lincoln, NE: iUniverse, 2003), 9-14.

11 See Shane White, Somewhat More Independent: The End of Slavery in New York City, 1770 -1810 (Athens: University of Georgia Press, 1991), 88-93; and Graham Russell Hodges, Slavery and Freedom in the Rural North:
} 
as rural New Jersey bondpeople (primarily males) broke sod, cleared forests, tended to livestock, and cultivated and carted produce, they lived and suffered in toxic white households where their actions were monitored. ${ }^{12}$ At times, this toxicity turned fatal.

In December 1752, for example, Jacob Van Neste, a wealthy farmer of Branchburg Township, Somerset County, was brutally murdered by his bondman. The incident stemmed from when Van Neste went inside the bondman's room where he was sitting, and took a small amount of tobacco from his box without permission (an act of hostile theft). The outraged bondman - a reputed "black wretch" who was large, athletic, and considered dangerous by the neighborhood whites - immediately plotted his revenge. One night, Van Neste went out visiting and, as he was putting away his horse in the barn, the bondman knocked him off the animal and "split his Skull" with an ax. He then dragged Van Neste's dead body at a distance and buried it in some brush. During the ensuing search for Van Neste, the bondman supposedly behaved in a strange manner that elicited suspicion against him. But the neighborhood whites were too afraid to arrest him. So they set him up; specifically, he was sent to fetch a log for a fire and, when he returned, a group of men jumped him. The bondman was later brought before a coroner's inquest, whereby he was made to touch Van Neste's dead body that instantly gushed blood; stung with guilt, he confessed to the murder. Though contrite during his interrogation, he demonstrated no such acquiescence at his public execution: while fastened to the burning stake, he shouted that his oppressors "had taken the Root but left the Branches." Not only does this man's defiance reflect his strong African roots

\footnotetext{
African Americans in Monmouth County, New Jersey, 1665-1865 (Madison, WI: Madison House, 1997), 16-21, 15556.

${ }^{12}$ On labor duties, see Hodges, Rural North, 44-47. On surveillance, see Robert K. Fitts, “The Landscapes of Northern Bondage," Historical Archaeology 30, no. 2 (1996): 54-73.
} 
(to show pain in West African society was considered dishonorable), but it also attests to his awareness that there existed many more "branches" or black insurgents like himself. ${ }^{13}$

Indeed, another deadly black branch rose up in October 1767, this time in nearby Hopewell Township, Hunterdon County. As he did every morning, Daniel Hart called up to his bondman Cuff, who was in his room asleep, telling Cuff it was time to go to work. Cuff, however, refused to heed Hart's call. Agitated, Hart went upstairs to confront Cuff but as soon as he "entered the Negro's Room, the Fellow stab'd him in several Places with his Knife." Cuff then pursued the staggering Hart down the stairs with his weapon and, when they moved outdoors, the bondman grabbed an ax with which he also used to mangle Hart, who suffered wounds to his head, arms, and back (he died from his injuries later in the day). The enslaver's young son, who heard screams while he was outside the house, rushed over to provide assistance. The son ran into Cuff, who slashed his face but he managed to escape. At that point, Cuff went back inside the house to probably murder his mistress, who had also absconded. Carrying his knife and ax, Cuff - who had attempted to escape on three separate occasions prior to the murder - then fled to the woods to elude an ensuing manhunt. Realizing the hopelessness of his situation, yet refusing to give whites the satisfaction of executing him, Cuff used a horse tether to hang himself in the woods. "His dead

\footnotetext{
${ }^{13}$ See New York Gazette Revived in the Weekly Post Boy, December 25, 1752 ("split his Skull”); Pennsylvania Gazette (Philadelphia), January 9, 1753 ("had taken the Root"); Andrew D. Mellick, Jr., The Story of an Old Farm; or, Life in New Jersey in the Eighteenth Century (Somerville, NJ: Unionist Gazette, 1889), 226 ("black wretch"); James P. Snell, comp., History of Hunterdon and Somerset Counties, New Jersey, with Illustrations and Biographical Sketches of its Prominent Men and Pioneers (Philadelphia: Everts and Peck, 1881), 759 (for how the bondman was set up); and Graham Russell Hodges, Root and Branch: African Americans in New York and East Jersey, 1613-1863 (Chapel Hill: University of North Carolina Press, 1999), 134-36 (for strong African roots). For other aspects of the murder, see Abraham Messler, Centennial History of Somerset County (Somerville, NJ: C. M. Jameson, 1878), 128-29; and Kenneth E. Marshall, Manhood Enslaved: Bondmen in Eighteenth- and Early Nineteenth-Century New Jersey (Rochester, NY: University of Rochester Press, 2011), 56, 79-80, 90, 104, 141.
} 
Body was burnt the Day after" its discovery as an apparent warning to the local blacks about the consequences of violent resistance. ${ }^{14}$

In the sensational homicides described above, one senses two bondmen who could no longer endure the degraded circumstances under which they were forced to exist. Walking time bombs, so to speak, the overwhelming anger they harbored got the better of them, and to their own personal detriment. We must consider four possible factors that fueled Harry Compton's own likely sense of anger correlating with his "instinctive desire to be free" - a correlation that manifested among other enslaved men. ${ }^{15}$ First, as a bondman, Compton was deemed an outsider who did not belong to the communities of his oppressors, thereby rendering him (as in the case of the Van Neste bondman) susceptible to endless white scrutiny. Second, he technically had no honor or dignity that whites were obligated to respect (hence, Van Neste's violation of his bondman's tobacco). ${ }^{16}$ Third, he lacked control over his body, and by implication over his time (even as he slept, like Cuff, he was expected to step lively at his enslavers' behest). ${ }^{17}$ Fourth, and lastly, he lacked control over his family ties. While he and his daughter, Dorcas, lived together for an undisclosed period under Richard Compton, his wife, Jude, and daughters Kate, Rachel, and Hannah evidently endured bondage elsewhere. We know that in 1803, Kate lived in Amwell

\footnotetext{
${ }^{14}$ For the details of the murder, see Pennsylvania Chronicle (Philadelphia), October 19, 1767 (which also mentions Cuff's previous escape attempts); Pennsylvania Gazette (Philadelphia), October 22, 1767; and New York Journal or General Advertiser, October 29, 1767 (quote). For the suicide and burning, see Pennsylvania Chronicle (Philadelphia), November 2, 1767.

${ }^{15}$ For this correlation, see, for example, Richard Allen, The Life, Experience, and Gospel Labours of the Rt. Rev. Richard Allen. To Which is Annexed the Rise and Progress of the African Methodist Episcopal Church in the United States of America. Containing a Narrative of the Yellow Fever in the Year of Our Lord 1793: With an Address to the People of Colour in the United States (Philadelphia: Martin and Boden, 1833), 11; and Interview with Henry Brandt, in Benjamin Drew, ed., A North-side View of Slavery: The Refugee: or, The Narratives of Fugitive Slaves in Canada. Related by Themselves, with an Account of the History and Condition of the Colored Population of Upper Canada (Boston: John P. Jewett, 1856), 345.

${ }^{16}$ See Orlando Patterson, Slavery and Social Death: A Comparative Study (Cambridge, MA: Harvard University Press, 1982), 10-12.

${ }^{17}$ See Marshall, Manhood Enslaved, 66-70.
} 
Township, Hunterdon County, with her three children Ben, Caleb, and Nancy. ${ }^{18}$ The exigencies of northern slavery made it very difficult for Compton to perform manhood as a responsible father and husband who provided for and protected his family. ${ }^{19}$

Despite the hardships he faced, Compton's anger is defused by Larison, who states that the bondman may have possessed "a vicious tendency" that facilitated his drive to freedom. For Larison, it was easier to envision Compton as "easy-going" and "flexible," as opposed to full of rage. ${ }^{20}$ Typical of nineteenth-century New Jersey white writers, Larison ignores northern bondage as a racial battleground, whereby resentful bondmen toughed it out under hostile and anxious enslavers. ${ }^{21}$ For example, although Van Neste was wealthy, successful, and highly respected in his community, he felt threatened by his bondman's size, strength, and athleticism. It seems doubtful that Van Neste would have violated this man's tobacco - his prized possession - had the enslaver been able to dominate the "black wretch" in the manner of those "old [New Jersey] masters," who Silvia Dubois insists "had no mercy on a nigger," violence that she bore witness to "many a time."22 Instead, Van Neste's authority had been reduced to petty bullying, which this prominent white man could not accept.

Physically powerful and wretched bondmen were not the only ones who raised the ire of their enslavers. Quamino Smock (1762-1850) reflects how following his religious conversion experience in Somerset County during the Revolutionary War, the young son of his Brokaw enslaver, who believed that religion created useless black servants, began to surveil the changed

\footnotetext{
${ }^{18}$ Compton's family members (except Kate) are mentioned in: Will and Inventory of Henry Compton, no. 2648. For Kate and her children, see Harry Compton Deed of Purchase, November 13, 1803, Pierpont Morgan Library, Gilder Lehrman Papers, New York City. Larison, Biografy, 53-54, notes that Silvia Dubois was born at Richard Compton's tavern, where she lived until around the age of two or three.

${ }^{19}$ See Marshall, Manhood Enslaved, 6, 72, 80, 106-7, 128-29, 131, 134.

${ }^{20}$ Larison, Biografy, 30.

${ }^{21}$ See Marshall, Manhood Enslaved, 36-37.

${ }^{22}$ Larison, Biografy, 66.
} 
bondman. One day, this son followed Quamino into the family barn to listen to the bondman pray, accusing him afterward of conversing with the devil, to which Quamino vehemently denied. Not surprisingly, years later, the "faithful servant" received a violent blow from the eldest Brokaw son, who was now his legal owner. The bondman's belief that he was a child of God - his "true master" - undermined the authority of Brokaw, who struck Quamino as a reminder of his dominance. In retaliation, Quamino quit Brokaw and found a new owner, a local custom (not law) used by other discontented enslaved people that required a great deal of conviction. ${ }^{23}$

Looking back, enslavers could turn irate at the least provocation on the part of bondmen, who could not count on the law to protect them from the wrath of enslavers' anxiety within their independent households, where their governance (and surveillance) was a private not public affair. ${ }^{24}$ Looking back, it behooved Compton to adopt a "vicious" temperament, for it is highly unlikely that he never ran up against white male hostility over his inner strength, selfdetermination, and physical potency. As one scholar reminds us, for enslaved males, "coming-ofage and personal development usually meant a clash with the slave system." ${ }^{25}$ This perhaps explains why Compton had three different enslavers. Of course, his turnover could have been related to economic exigencies, that is, his enslavers unloaded him for financial reasons. ${ }^{26}$ Yet another plausible consideration is that his desire for freedom, which was no secret, did not make for harmonious black-white relations. Enslaved people were required to suffer their indignity in

\footnotetext{
${ }^{23}$ William J. Allinson, Memoir of Quamino Buccau, A Pious Methodist (Philadelphia: Henry Longstreth, 1851), 6-8, 9-10 ("faithful servant" on 9); referenced in Marshall, Manhood Enslaved, 96-104 ("true master" on 100). On the custom of changing owners, see also Billy G. Smith, "Black Women Who Stole Themselves in Eighteenth-Century America," in Inequality in Early America, ed. Carla Gardina Pestana and Sharon V. Salinger (Hanover: University Press of New England, 1999), 144.

${ }^{24}$ See John Wood Sweet, "Venture Smith and the Law of Slavery," in Venture Smith and the Business of Slavery and Freedom, ed. James B. Stewart (Amherst: University of Massachusetts Press, 2015), 83-85.

${ }^{25}$ Christopher B. Booker, "I Will Wear No Chain!": A Social History of African American Males (Westport, CT: Praeger, 2000), 36.

${ }^{26}$ For such an example, see Marshall, Manhood Enslaved, 110.
} 
silence; those who did not undermined enslavers" household authority. ${ }^{27}$ The "vicious" or fierce Compton that Larison found to be unpalatable corresponds with someone who resented, and sought ways to transform, his degraded condition - an agenda that ran counter to his enslavers' hegemony. Did not public demonstrations of his physical dominance assist in this process, serving notice that despite his enslavement, he was very much a man? In the words of Michael Kimmel, "violence has [historically] been understood as the best way to ensure that others publicly recognize one's manhood." 28

But where could Harry showcase his physical dominance? Where did he put white and black men on the ground under rural northern slavery, an institution characterized by white majorities and limited social interaction between blacks? ${ }^{29}$ Richard Compton's hotel and tavern makes the most logical sense.

Taverns and inns (or, more properly, public houses) served a variety of purposes in eighteenth-century New Jersey towns and countrysides, such as providing travelers with overnight lodging and a place where they could eat, drink, and be entertained. Taverns, moreover, functioned as community centers where the locals came together to get news of the outside world in a newspaper that passed through many hands, to discuss matters of public interest, to indulge in amusements, to engage in competitions, and of course to drink. In other words, taverns emerged as gendered spaces that enabled men to socialize and drink with each other as well as demonstrate

\footnotetext{
${ }^{27}$ On silence, I draw on Alex Bontemps, The Punished Self: Surviving Slavery in the Colonial South (Ithaca, NY: Cornell University Press, 2001), 117, 120-21.

${ }^{28}$ Michael Kimmel, "Violence," in Men and Masculinities: A Social, Cultural, and Historical Encyclopedia, ed. Kimmel and Amy Aronson, 2 vols. (Santa Barbara, CA: ABC-CLIO, 2003), 2: 811.

${ }^{29}$ On ethnic isolation, see White, Somewhat More Independent, 93, 134-38; Hodges, Rural North, 17, 43-44, 77-79, 187; and Marshall, Manhood Enslaved, 111-15. In 1790, around the time Harry gained his freedom, the 405 blacks (386 enslaved and 19 free) in Hillsborough accounted for just 18.4 percent of the township's total population. See US Census Bureau, A Century of Population Growth from the First Census of the United States to the Twelfth, 1790-1900 (Washington, DC: Government Printing Office, 1909), 195.
} 
their masculine prowess. ${ }^{30}$ In 1700, for example, Lewis Morris, an American colonial official and future royal governor of New Jersey, wrote to the bishop of London, complaining about what he considered was the uncivilized sporting culture in rural Middletown, Monmouth County. These "most ignorant and wicked people," Morris reported, held their Sunday church meetings "at a Publick house, where they get their fill of Rum, and go to fighting and running of [horse] races which are Practices much in use that day all the Province over." ${ }^{31}$ Further, it is said that visitors at The Tavern in the Woods (later Woods Tavern) in Hillsborough Township were "almost immediately put on [their] mettle, and tests of strength would follow, to the great delight of hangers-on." 32 General Training in New Jersey, a one-day interracial affair held in June that celebrated the troops of a county militia as they assembled and went through their drills, emerged as an alternative masculine proving ground at the end of the Revolutionary War. One New Jersey writer describes "training-day fights" as "a mixture of tests of strength and personal antagonisms ...held in the stable yards of taverns, when eye-gouging and chewing of ears were allowable under rough and ready 'rules' governing such affairs.",33

In sum, although the historical record remains silent on what occurred at Richard Compton's hotel and tavern, the received wisdom suggests that it, too, was a site of masculine competition and violence. Harry Compton, so it appears, proved his worth, and thereby enhanced his public reputation, at the hotel and tavern amid a mix of patrons that included "small farmers,

\footnotetext{
${ }^{30}$ See Francis Bazley Lee, New Jersey as a Colony and as a State: One of the Original Thirteen, 4 vols. (New York: Lewis Historical Publishing, 1902), 1: 291-94, 301; 2: 450-51; and Charles S. Boyer, Old Inns and Taverns in West Jersey (Camden, NJ: Camden County Historical Society, 1962), 2-8, 11-13.

${ }^{31}$ Quoted in Lewis Morris, The Papers of Lewis Morris, Governor of the Province of New Jersey, from 1738 to 1746 (New York: George P. Putnam for the New Jersey Historical Society, 1852), 8-9.

32 According to Walter Van Hoesen, "The original hostelry [established around 1726] was near the present Route 206 running from Somerville to Princeton." Van Hoesen, Early Taverns and Stagecoach Days in New Jersey (Rutherford, NJ: Fairleigh Dickinson University Press, 1976), 47.

${ }^{33}$ Lee, New Jersey as a Colony and as a State, 2: 454. See also Larison, Biografy, 67, 74-75; and Mellick, Old Farm, 577-78, 607.
} 
artisans, laborers, and slaves" - a group that, we are told, typically assembled in the yards of such establishments in New Jersey. ${ }^{34}$ To further illustrate, a false pronouncement of Dubois's death noted that at her former owner's hotel and tavern in Great Bend, Pennsylvania, "she became famed for her feats of strength and for the prize fights in which she engaged." 35 Aside from taverns, there existed few public settings in the rural North where blacks could safely establish a reputation for defeating men, especially white men, in combat. Thus, it is no surprise that when Harry Compton erected Put's Tavern, it served as a venue where white and black men could fight along lines of equality. A visitor at the tavern recalls witnessing a vulgar interracial social scene where people placed bets on and formed a ring "around two bullies, one a white man, the other black, fighting for no other reason than to see which could whip." ${ }^{\prime 36}$ There can be little doubt that this egalitarian interracial fighting was rooted in Compton's enslavement at his former owner's establishment, where he displayed his noted physical strength and fighting ability.

The pugilistic exploits of Dubois's daughter, Elizabeth Alexander (b. circa 1824), shed important light on Compton's reputation in these areas. A large and physically imposing woman like her mother, Alexander reputedly engaged in hand-to-hand combat against the "bullies" on Sourland Mountain, participated "in many a prize fight," and did not care "whether the champion who was to meet her was male or female." She is also said to have "gone a long distance to meet the champion who dared to challenge her, or to provoke her ire." ${ }^{\prime 37}$ As in the case of enslaved

\footnotetext{
${ }^{34}$ Lee, New Jersey as a Colony and as a State, 1: 292.

${ }^{35}$ Manning Times (Manning, South Carolina), March 28, 1888. According to Dubois's will, she actually died on May 1, 1888. See Will of Sylvia Dubois, no. 9013, NJSA. The fact that few blacks lived in Great Bend at this time suggests that Dubois defeated mostly white men in combat. On Dubois's lack of a black social network in Great Bend, see Kenneth E. Marshall, “'I Belong to No Man': Self-Possession through Mobility in Silvia Dubois, a Biografy of the Slav Who Whipt Her Mistres and Gand Her Fredom,” Journal of African American History 104, no. 4 (2019): 570. ${ }^{36}$ Larison, Biografy, 32.

${ }^{37}$ Ibid., 85-86 (quotes on 86; original pagination). Larison refers to this daughter variously as Elizabeth, Lizi, and Lizi Dubois, but she appears in her mother's 1889 will as Elizabeth Alexander. See Will of Sylvia Dubois, no. 9013. The approximation of Alexander's year of birth is derived from Lobdell, introduction to Biografy, 11.
} 
southern women delineated by Jeff Forret, the use of violence apparently blurred the boundaries between "masculine" and "feminine" in the life of Alexander, a vehicle through which she (like her mother) gained respect on rough and tumble Sourland Mountain. ${ }^{38}$ Alternatively, her actions suggest how champion fighters on the mountain were accorded status and respect; champions invited challenges from those seeking (re)validation of their prowess and worth. Did not Compton - a champion in his own right - provoke the ire of white and black men in search of such validation to seek him out? Was he never required to defend his reputation for putting men on the ground among the mountain "bullies"? While hindered in his ability as a father and husband, the bondman achieved status in the arena of fighting - a realized form of power for him and, later, for his female family members who followed in his path.

Drawing from Sergio Lussana's penetrating analysis of slave fighting on antebellum southern plantations, Compton, who Dubois implies was "very active" when he fought, probably defeated his rivals by using combinations of speed, stamina, and strength that demonstrated mastery over his body. This fighting mastery, arguably, in addition to enabling Compton to reclaim his body subjected to the dictates, indignities, and anxieties of bondage, also served as an important outlet for his anger and frustration. The human ring that would have formed around Compton and his opponents (e.g., Put's Tavern), whereby onlookers could both judge and celebrate the characteristics of his fighting, was crucial, for it allowed Compton to demonstrate his mastery in the public eye. Compton's fighting, in other words, was in part a public performance that drew attention to himself. ${ }^{39}$ Dubois's aforementioned comment that the elderly Compton danced publicly in Princeton, New Jersey, bespeaks a person who greatly desired to be seen by society. Fighting proved imperative to that end; as he publicly used his stout and powerful body in combat,

\footnotetext{
${ }^{38}$ Forret, Slave against Slave, 340-42, esp. 342.

${ }^{39}$ Lussana, My Brother Slaves, 61-62.
} 
Compton gained much-coveted recognition. Accordingly, Larison states that "in the struggle for life, Silvia incurred many a combat; and, although she always came off from the field victorious, sometimes she did not come off unscathed." Several men, he adds, testify to her prowess, remembering how she could throw brawling men in different directions at Put's Tavern with ease. ${ }^{40}$ Like that of his granddaughter, Compton's body during such public altercations, or performances, when it became "active" on his own terms, was made visible to a white hegemonic society forced to take account of the mighty bondman's existence.

\section{War and the Evolution of Masculinity}

Surely, however, Compton was not content with how his ability to physically dominate other men enhanced his public visibility. His "instinctive desire to be free" speaks not only to his anger, but also to his ability to see life as possibility instead of devoid of hope. The Revolutionary War, arguably, played an important role in promoting this vision, facilitating a process by which Compton performed manhood in several other notable ways that further defied his degraded status and, eventually, led to him gaining his freedom and taking control of his life and body.

Owing to the British military occupation of New York City and New Brunswick (located partly in Somerset and Middlesex counties), the Revolution frequently traversed central New Jersey, resulting in a great deal of social turmoil that included an upsurge in resistance among the enslaved, with many captives deciding to run away. ${ }^{41}$ For Compton, whose family appears

\footnotetext{
${ }^{40}$ Larison, Biografy, 60-62 (quote on 60; original pagination).

${ }^{41}$ Central New Jersey is defined here as the Somerset-Middlesex-Hunterdon counties area. On the area's geographic importance during the Revolution, see Leonard Lundin, Cockpit of the Revolution: The War for Independence in New Jersey (Princeton, NJ: Princeton University Press, 1940), chap. 6; and T. J. Luce, New Jersey's Sourland Mountain (Neshanic Station, NJ: Sourland Planning Council, 2001), chap. 9. See also William Schleicher and Susan Winter, "Patriot and Slave: The Samuel Sutphen Story," New Jersey Heritage 1, no. 1 (2002): 35-38. British forces occupied New Brunswick from 1776 to 1777, and New York City from 1776 to 1783. On black resistance in New Jersey, see Hodges, Rural North, chap. 3; Hodges, Root and Branch, chap. 5; Graham Russell Hodges, Black New Jersey: 1664 to the Present Day (New Brunswick, NJ: Rutgers University Press, 2018), 38-42; Giles R. Wright, "Moving Toward Breaking the Chains: Black New Jerseyans and the American Revolution," in New Jersey in the American Revolution, ed. Barbara J. Mitnick (New Brunswick, NJ: Rutgers University Press, 2005), 126-28; Marshall, Manhood Enslaved,
} 
fragmented at this time, running away does not seem to have been a viable option. Instead, like other enslaved and free blacks who supported the Patriot cause and made vital contributions as soldiers, guides, scouts, spies, foragers, boat pilots, wagon drivers, and musicians, he cast his lot with the rebels. ${ }^{42}$ Cornelius Larison explains that this "fifer of note in the army of the Revolution" had established a reputation for "honorable" behavior, suggesting that military service provided another invaluable stage for Compton to prove his worth. ${ }^{43}$ Similarly, Craig Smith argues that free and enslaved African American men actively pursued the mantle of honor through military service on the Patriot side and, in the process, challenged the views of General George Washington, who previous to the Revolution believed that this ideal was beyond the pale of black men. The valor demonstrated by African American soldiers, compelled Washington - a southern slaveholder who initially was against black men serving in the military - to reverse his views. ${ }^{44}$

Both Oliver Cromwell (1752-1853) and Samuel Sutphen (1747-1841) warrant our consideration as respected former African American soldiers. After serving in the Second New Jersey Regiment, Cromwell, who was possibly born free, applied for a war pension from the US

72-77; and James J. Gigantino II, Ragged Road to Abolition: Slavery and Freedom in New Jersey, 1775-1865 (Philadelphia: University of Pennsylvania Press, 2015), 46-53.

${ }^{42}$ For general discussions on black Patriots, see Benjamin Quarles, The Negro in the American Revolution (Chapel Hill: University of North Carolina Press, Omohundro Institute of Early American History and Culture, 1961), chap. 5, 94-100; and Sidney Kaplan and Emma Nogrady Kaplan, The Black Presence in the Era of the American Revolution, rev. ed. (Amherst: University of Massachusetts Press, 1989), 32-68. On black Patriots in New Jersey, see, for example, Frances D. Pingeon, Blacks in the Revolutionary Era, New Jersey's Revolutionary Experience 14 (Trenton: New Jersey Historical Commission, 1975), 20-21; Schleicher and Winter, "Patriot and Slave," 30-43; Wright, "Breaking the Chains," 129-30; Hodges, Root and Branch, 140-44; Hodges, Black New Jersey, 42-44; Gigantino, Ragged Road, 53-57; and Elaine Buck and Beverly Mills, If These Stones Could Talk: African American Presence in the Hopewell Valley, Sourland Mountain, and Surrounding Regions of New Jersey (Lambertville, NJ: Wild River Books, 2018), 135-36, 139-41, 160-62, 172-74, 178-79.

${ }^{43}$ Larison, Biografy, 28. I have accepted Larison's statement regarding Compton's military service, albeit no other records verify it, save the newspaper account of Silvia Dubois mentioned in n. 10, above. Compton, I have assumed, was among the many black soldiers whose military service during the Revolution went undocumented on the muster rolls. (This point is raised again in $\mathrm{n}$. 46, below.) In my estimation, Larison had no reason to embellish this part of Compton's story.

${ }^{44}$ Washington's changing attitude toward black enlistment owed to military necessity. Craig Bruce Smith, American Honor: The Creation of the Nation's Ideals during the Revolutionary Era (Chapel Hill: University of North Carolina Press, 2018), 112-17. 
government in 1818, but was denied in his request. However, with the support of prominent white male Burlington County citizens, he received a pension in 1820. Three decades later, the Burlington Gazette informed its readers in 1852 that Cromwell, now a centenarian, was "among the survivors of the gallant army who fought for the liberties of our country, in the days which tried men's souls." When reflecting on his war experiences to the newspaper, the elderly selfdescribed drummer humorously stated with pride how he and his fellow soldiers "knocked the British about lively" in the Battle of Princeton. ${ }^{45}$ In his 1834 deposition for a war pension, Sutphen, who served in the Patriot army in place of his enslaver with the hope of gaining his freedom afterward, contended that "fighting for the white man's freedom" justified financial support from the federal government. As with Cromwell, prominent white males of Somerset County supported Sutphen's application, describing the venerable black man as possessing "a good character in every point of view." After the US War Department denied his application five times, in 1836, at age eighty-nine, Sutphen received a pension from the New Jersey Legislature. ${ }^{46}$ In their respective comments about giving the British a "lively" drubbing and "fighting for the white man's freedom," Cromwell and Sutphen staked their claim to the masculine heritage of the Revolution, which

\footnotetext{
${ }^{45}$ Oliver Cromwell Federal Pension Application, Series M805, Roll 233, File S34613, National Archives, Washington, DC (hereafter cited as National Archives). Quoted in William C. Nell, The Colored Patriots of the American Revolution: With Sketches of Several Distinguished Colored Persons: To Which is Added a Brief Survey of the Condition and Prospects of Colored Americans (Boston: Robert F. Wallcut, 1855), 160-62 ("among the survivors" on 160, "knocked the British about lively" on 161). See also Kaplan and Kaplan, Black Presence, 52, 54. Under the category of "occupation," Cromwell is listed as "drummer in Revolution," in US Census, 1850: Burlington County, New Jersey, Roll: M432-443, 21A, NJSA.

${ }^{46}$ For quotes, see Samuel Sutphen Federal Pension Application, Series M805, Roll 783, File R10321, May 26, 1834, National Archives. For Sutphen's account of his military service, see also A. Van Doren Honeyman, ed., "The Revolutionary War Record of Samuel Sutphin, Slave," Somerset County Historical Quarterly 3 (1914): 186-90, as reprinted in Larry R. Gerlach, ed., New Jersey in the American Revolution, 1763-1783: A Documentary History (Trenton: New Jersey Historical Commission, 1975), 354-60. For the pension, see Acts of the Sixtieth General Assembly of the State of New Jersey (Trenton: William Boswell, 1836), 402. William Schleicher and Susan Winter state the following with regard to Sutphen's lack of success in gaining a federal war pension: "For one thing, his name does not appear on any of the official rosters. But the matter seemed to boil down to the fact that those in Washington who considered applications, felt that the benefit of the service of a slave should accrue to his master, and that therefore Samuel was not entitled to any benefit, even though he had served faithfully." Schleicher and Winter, "Patriot and Slave," 43.
} 
valorized them as men deserving of respect (and compensation). Whatever their feelings about black people as a whole, some whites felt obligated to advocate on the behalf of black men who gallantly fought for American liberty. ${ }^{47}$

Given the respect associated with military service in the Patriot army, it is no wonder that Compton and his enslaved son-in-law, Cuffy Baird, assumed the role of fifer. Silvia Dubois proudly recalled that Baird, her father who eventually gained his freedom, "was a fifer in the Battle of Princeton. He used to be a fifer for the minutemen in the days of the Revolution."48 Both fifers and drummers (considered as non-combatants as they did not bear arms) served as critical agents of army communication, transmitting the signals and directives of the officers to the troops. Among these musicians' many responsibilities, they announced the day's activities in camp, directed the movement of the troops on the loud and dangerous battlefield (left unprotected they suffered high casualties), set the cadence for the soldiers during marches, and played tunes that elevated martial spirit and morale. ${ }^{49}$ Some performed their duties while displaying a real aptitude for music. Captain John Ford, for example, described Barzillai Lew (1743-1822), a free black who enlisted in Ford's company from Chelmsford, Massachusetts, and who played his fife during the Battle of Bunker Hill, as “big and strong with an extraordinary talent as a musician.” Lew's talent earned him the distinguished position of company fifer. ${ }^{50}$ We can assume that, as a "fifer of note,"

\footnotetext{
${ }^{47}$ On white advocacy of black soldiers, see Smith, American Honor, 115, 116.

${ }^{48}$ Larison, Biografy, 53. No official military records explicitly support Dubois's statement regarding her father's war service. However, a "Negro Cuff fifer," who may well have been her father, is listed as having served in the Third New Jersey Regiment. In any case, I accept her statement as true. For military listing, see Buck and Mills, If These Stones Could Talk, 139, 160. Cuffee Baird is listed as the head of a free black household in Hillsborough Township in 1830 with six other occupants, in Carter G. Woodson, Free Negro Heads of Families in the United States in 1830, together with a Brief Treatment of the Free Negro (Washington, DC: The Association for the Study of Negro Life and History, 1925), 83.

${ }^{49}$ See Harry M. Ward, George Washington's Enforcers: Policing the Continental Army (Carbondale: Southern Illinois University Press, 2006), chap. 15.

${ }^{50}$ Quoted in Catherine Reef, "Lew, Barzillai (1743-1822): Revolutionary War Fifer," in Reef, African Americans in the Military (A to Z of African Americans) (New York: Facts on File, 2004), 143-44 (quote on 144). On Lew, see also Kaplan and Kaplan, Black Presence, 21-22.
} 
Compton demonstrated some level of musical talent that also attracted attention. In a way, playing the fife boosted his already exalted masculine prowess as a fighter and dancer, that is, these attributes created a potent image of black masculinity.

In the end, serving as a fifer - a position of responsibility, notoriety, and visibility provided Compton an all-important vehicle of self-transformation. Mechal Sobel argues that during the "greater Revolutionary period" of 1740 to 1840, many people living on the margins of society (women, blacks, and poor whites) “engaged in 'fantasies of freedom' as well as acts intended to change both their selves and their social situations." ${ }^{51}$ Compton's military service represents one of his "acts," which he apparently used to press for his freedom; indeed, most enslaved northerners, posits John Sweet, gained freedom "by taking matters into their own hands and driving the best bargains they could." ${ }^{52}$ Richard Compton - himself a military man - may have found it difficult not to negotiate with his determined bondman, who had now proven his worth on the biggest public stage possible; as a fifer, the "farseeing Negro" (Larison's words) gave the defining performance of his life, one that his enslaver could not ignore. ${ }^{53}$ The intimate nature of northern bondage, which fostered violent conflict between black and white men, also provided the enslaved "with some leverage when dealing with their owners." 54

It would be interesting to know the terms of Compton's agreement to purchase his freedom, namely, how much money was involved and by what time it was owed. Yet Larison makes no mention of this matter in the Biografy. Nevertheless, the price was doubtlessly substantial. "Even under the best circumstances," emphasizes a noted historian, "self-purchase was an enormous

\footnotetext{
${ }^{51}$ Mechal Sobel, Teach Me Dreams: The Search for Self in the Revolutionary Era (Princeton, NJ: Princeton University Press, 2000), 3-9 ("greater Revolutionary period" on 3, "engaged in "fantasies of freedom"” on 9).

${ }^{52}$ Sweet, "Venture Smith and the Law of Slavery," 111.

${ }^{53}$ Larison, Biografy, 28. Richard Cumpton (Compton) is listed as having "served under Capt. Jacob Ten Eyck in the Revolutionary War, from the year 1775 to the year 1781, at different times," in Messler, Centennial History of Somerset County, Appendix (5).

${ }^{54}$ Marshall, Manhood Enslaved, 116.
} 
[financial] undertaking"; thus, "many failed." 55 The ability to purchase his freedom symbolized another critical public stage for Compton to demonstrate his worth as a man. Failure on this stage would have curtailed his masculine development, proving that he was just another black person incapable of exercising independent manly adulthood, a sentiment that permeated American culture and society in the late eighteenth century. ${ }^{56}$ While on this stage, Compton now lived in "quasi freedom," that is, halfway between slavery and freedom. Although legally enslaved, he could pursue his own economic endeavors, perhaps provide greater support to his fragmented family, and exercise greater mobility - the domain of free white men. ${ }^{57} \mathrm{He}$ could ill-afford to squander such an opportunity.

To raise the money for his freedom project, Compton turned to Sourland Mountain. He probably learned from his labor experiences under rural New Jersey slavery that charcoal, a highly coveted commodity used to make iron in eighteenth-century forges and furnaces, derived from trees that the sprawling mountain possessed in mass abundance. ${ }^{58}$

Making charcoal was a laborious, dirty, and dangerous enterprise that required some skill. Like any charcoal burner, or collier, Compton had to first cut down trees and chop them into a desired length (around four feet long). He then needed to stack the chopped up trees in a moundlike shape to form a coaling pit, and cover the structure with a thick layer of turf and sand, making

\footnotetext{
${ }^{55}$ Loren Schweninger, "From Assertiveness to Individualism: The Difficult Path from Slavery to Freedom," in American Chameleon: Individualism in Trans-National Context, ed. Richard O. Curry and Lawrence B. Goodheart (Kent, OH: Kent State University Press, 1991), 128.

${ }^{56}$ See Bruce Dorsey, Reforming Men and Women: Gender in the Antebellum City (Ithaca, NY: Cornell University Press, 2002), 14-20.

${ }^{57}$ On "quasi freedom," see Schweninger, "From Assertiveness to Individualism," 126. On travel or mobility as a "free white masculine domain," see Elizabeth Stordeur Pryor, Colored Travelers: Mobility and the Fight for Citizenship before the Civil War (Chapel Hill: University of North Carolina Press, 2016), chap. 2 (quote on 47). See also Marshall, "'I Belong to No Man,"” 553-83.

${ }^{58}$ Sourland Mountain is approximately four miles wide and seventeen miles long, extending all the way from the Delaware River to just beyond the town of Neshanic in Hillsborough Township. In terms of height, however, it is not nearly as impressive, reaching a maximum elevation of 568 feet above sea level. See Luce, Sourland Mountain, 1.
} 
it airtight. This method would have enabled Compton to control the combustion process and prevent the wood from going up in flames and turning into useless ash. After igniting the mound, day and night he had to monitor the smoke coming from the holes poked in the mound to ensure that it burned properly: white smoke signified progress and blue smoke a fire, meaning the potential loss of his precious labors. Since making charcoal was "a twenty-four-hour-a-day job," it may have called for Compton to build and live in a shack near his coal pits. Indeed, he could only engage in this time-consuming enterprise, which typically took fourteen days to complete, while living in "quasi freedom." Once the wood finally turned into coal, the mound had to settle. Subsequent to the cooling period, he needed to carefully gather the charcoal using a wooden rake, shovel, or basket "to limit breakage and lower the chance of causing sparks that sent [his] work up in flames." He later stored it for sale; his customers were most likely local ironmasters and blacksmiths (as context, in 1828, Samuel Wright [1781-1845], a Quaker entrepreneur based in Monmouth County, contracted to deliver charcoal to a merchant in the port and market town of New Brunswick). ${ }^{59}$

In the final analysis, Compton mastered his physical surroundings, thereby demonstrating his ability to control his own destiny. He astutely placed his faith in the lucrative production of charcoal, an indication of not only his tenacity, but also of his sense of business acumen. $\mathrm{He}$ apparently understood how making charcoal could quickly change his life. "The rapid increase turnover of charcoal potentially empowered colliers," remarks a historian. ${ }^{60}$

\footnotetext{
${ }^{59}$ My understanding of charcoal making is greatly indebted to Richard Veit, Digging New Jersey's Past: Historical Archaeology in the Garden State (New Brunswick, NJ: Rutgers University Press, 2002), 156-57 ("twenty-four-houra-day" on 157); and John Bezis-Selfa, Forging America: Ironworkers, Adventurers, and the Industrious Revolution (Ithaca, NY: Cornell University Press, 2004), 27-31 ("to limit breakage" on 31). On Wright, see Kenryu Hashikawa, "Rural Enterprise and the Northern Economy in the Early Republic: The New Jersey Charcoal Venture as a Test Case," The Japanese Journal of American Studies no. 15 (2004): 102.

${ }^{60}$ Bezis-Selfa, Forging America, 29.
} 
Although a remarkable individual achievement, Compton's charcoal scheme also represents a broader trend in heroic economic activity among enslaved people. Born free in West Africa but enslaved as a boy, Venture Smith (c. 1729-1805) would go on to become the best known enslaved northern black who made good. Over the course of nearly five years in southern New England, Smith raised the money to purchase his freedom in 1765 , by doing side jobs such as threshing grain and using his Herculean physical strength to cut vast amounts of cordwood. Within a decade, Smith purchased the freedom of his wife and children through a range of activities that included cutting more cordwood, chartering a sloop to ply his wood trade, fishing for eels and lobsters, and working as a sailor on a whaling voyage. ${ }^{61}$ Sutphen represents another important example of black self-determination under northern bondage. At the beginning of the Revolution, Sutphen, enslaved in Somerset County, agreed to do militia duty in the stead of Hunterdon County resident, Caspar Berger, in exchange for his freedom. Berger, who had purchased Sutphen for that sole purpose, not only reneged on his promise to free Sutphen after the bondman completed his military service, but he also sold the war veteran. Several conscientious whites intervened in the matter, ultimately failing in their attempt to have Sutphen liberated. Yet, around 1805, the resilient Sutphen had bought his freedom (from his fifth enslaver) with the money he saved from "selling furs and skins of rabbits, raccoons \& muskrats." 62

Compton, Smith, and Sutphen exemplified the doggedness of many enslaved northern blacks to become free against the odds. Smith's legendary exploits, however, are preserved for posterity in his dramatic and carefully crafted 1798 autobiography that shows how through his

\footnotetext{
${ }^{61}$ Venture Smith, A Narrative of the Life and Adventures of Venture, a Native of Africa: But Resident above Sixty Years in the United States of America. Related by Himself (New London, CT: C. Holt, 1798), 5, 9-11, 18, 21, 22-27, docsouth.unc.edu/neh/venture.html (accessed April 13, 2018).

${ }^{62}$ Samuel Sutphen Federal Pension Application, August 15, 1832, and May 26, 1834 (quote). See also Schleicher and Winter, "Patriot and Slave," 41.
} 
persistence, frugality, and self-control, he was able to uplift himself and live out the ideal of American freedom. Smith, writes Robert Desrochers, Jr., "held himself up [in his narrative] as the true revolutionary son - an African son at that."63

Had Compton spoken for himself in his own narrative, he may have pondered how his military service and charcoal making enterprise confirmed him as a "true revolutionary son." The latter activity captures the thinking of common American men and women who, after 1776, avers Seth Rockman, equated personal freedom with the ability "to work when and where they wanted, to pursue their own interests free from government interference, to succeed or fail as the impartial forces of the market dictated, and to control their own destinies in a society of boundless opportunity." 64 To put it another way, making charcoal allowed Compton to control his labor (and hence his body), to pursue his own interests without white interference, to engage in a viable market, and to exploit the economic potential of his physical surroundings. In an interesting turn of events, Compton, like the famed Smith before him, had gone "from being an object of the commercial marketplace to being an agent within [it]. ${ }^{65}$ The fighter turned honorable soldier had now become a man of business.

As best as we can tell, Compton purchased his freedom between the years 1785 and 1790, when he was in his 40s, and left Hillsborough Township around $1792 .{ }^{66}$ Free blacks, in addition

\footnotetext{
${ }^{63}$ Robert E. Desrochers, Jr., “'Not Fade Away': The Narrative of Venture Smith, an African American in the Early Republic," Journal of American History 84, no. 1 (1997): 50.

${ }^{64}$ Seth Rockman, "The Unfree Origins of American Capitalism," in The Economy of Early America: Historical Perspectives and New Directions, ed. Cathy Matson (University Park: Pennsylvania State University Press, 2006), 336.

${ }^{65}$ Anna Mae Duane, "Keeping His Word: Money, Love, and Privacy in the Narrative of Venture Smith," in Venture Smith and the Business of Slavery and Freedom, Stewart, 190.

${ }^{66}$ A 1784 census of Hillsborough Township indicates that Richard Compton owned two bondpeople (evidently Harry and Dorcas), whereas the Hillsborough tax ratables for 1790 do not list Richard Compton as owning any blacks. Presumably, then, Harry purchased his freedom from Richard between 1785 and 1790 . Hillsborough tax ratables for the period 1790-1792 list a Harry Compton, a "single man" who did not own any real estate, perhaps our subject. See "Hillsborough Township 'Census' of 1784," 2 (2): 103; and Tax Ratables, Hillsborough Township, Somerset County, 1790-1792, Books 1739, 1740, 1741, Reel 18, NJSA.
} 
to their low percentages in Somerset County and throughout the post-Revolutionary countryside of New York City, faced severe constriction in their lives. As Graham Hodges describes the situation, "lacking political power and credit and with tiny incomes, unable to buy land, free blacks combined hiring out their backs to white farmers with part-time labor on their own miniscule plots of land." In search of economic opportunities and a more satisfying cultural life, Hodges points out, hundreds of newly freed blacks abandoned the countryside for the city in the 1780 s. ${ }^{67}$ No doubt, the 19 free blacks living in Hillsborough Township in 1790 testify to this racially restricted existence and migration trend, and illuminate why Compton left the area. ${ }^{68}$ To this point, Compton - despite the danger involved - stayed on the move, even as an elderly man whom Dubois insists “was yet quite active." Compton's defiance of the criminalization of black mobility in eighteenthand early nineteenth-century New Jersey suggests that he departed Hillsborough Township to claim agency over his life and body. ${ }^{69}$

Compton turns up in an 1803 deed of purchase that describes him as "a free African" living in New Brunswick, Middlesex County (one wonders if he plied his charcoal enterprise in the port and market town). The document also notes that Compton, in two separate installments totaling $\$ 145$, purchased the freedom of his daughter, Kate, and her three children - testifying to his family dedication. ${ }^{70}$ It is possible that he purchased other family members while in New Brunswick, but this does not appear in the documents. Yet, it is clear that he never purchased Dorcas, who was living in New Brunswick in the early 1800s, and who died there in bondage around $1838 .^{71}$ This may have proved devastating to Compton, a harsh reminder of the limits of his personal power. If

\footnotetext{
${ }^{67}$ Hodges, Root and Branch, 175-76 (quote on 175).

${ }^{68}$ See n. 29, above.

${ }^{69}$ Larison, Biografy, 70. This observation draws on Marshall, “'I Belong to No Man, ’” 553-54, 558-64.

${ }^{70}$ Harry Compton Deed of Purchase, 1803. It is unclear whether the cultural referent - "African" - was a white-written appellation for black, or a prideful admission by Compton of his African heritage.

${ }^{71}$ See Larison, Biografy, 12, 54-55, 69.
} 
not, then living in New Brunswick certainly challenged his resolve, for the town's free blacks ran up against menial employment, housing discrimination, and racialized police surveillance. ${ }^{72}$

Nevertheless, in the aforementioned deed of purchase, Compton "solemnly declare[d] himself to be a manumit \& free from bondage to man or set of men." ${ }^{.73}$ Using language reminiscent of the Patriot rebels, Compton affirms that his life and body belong only to himself and not to some other man or governing body; the freedman was his own master. In the antebellum urban North, observes James Horton, "gender ideals of black society were heavily influenced by middle class black males," who admonished their brethren to become "masters" of their and their families" lives, stressing the importance of entrepreneurship and acquiring trade skills. ${ }^{74}$ How did Compton put the gender ideal of self-mastery into practice?

\section{Master of His Own World}

Perhaps after he tired of New Brunswick, Compton returned to Sourland Mountain, where his life reached new heights. In 1812, "Harry Compton (a black-man) of the Township of Amwell" - and a current landowner - purchased one parcel of land from the family of Philip Servis, Jr., and another parcel, a year later, from the family of Abraham Kise. ${ }^{75}$ These land purchases increased Compton's property on which he built Put's Tavern, established at some point between 1803 and 1812 (probably closer to 1803 when he lived in New Brunswick). Compton, whom I suspect operated his establishment for roughly a decade, became empowered like never before as both the owner of land and a popular tavern. ${ }^{76}$ The importance of "home" or "place" in the lives of free

\footnotetext{
${ }^{72}$ See Shaun Armstead et al., “'And I Poor Slave Yet': The Precarity of Black Life in New Brunswick, 1766-1835,” in Scarlet and Black: Slavery and Dispossession in Rutgers History, ed. Marisa J. Fuentes and Deborah Gray White (New Brunswick, NJ: Rutgers University Press, 2016), 91-122.

${ }^{73}$ Harry Compton Deed of Purchase, 1803.

${ }^{74}$ James Oliver Horton, "Freedom's Yoke: Gender Conventions among Antebellum Free Blacks," in Horton, Free People of Color: Inside the African American Community (Washington, DC: Smithsonian Institution Press, 1993), 102-4 ("gender ideals of black society" on 102, "masters" on 103).

${ }^{75}$ Hunterdon County Deed Book, 25: 322-25, NJSA.

${ }^{76}$ Larison, Biografy, 28, contends that Compton was "for many years [the tavern's] proprietor."
} 
black men tells us that he did not purchase land simply to convey economic superiority, but rather to shed the remnants of his former enslavement and to secure a solid, autonomous place that shielded him from America's racism. ${ }^{77}$

On the other hand, land ownership eluded many free blacks such as Prime, whom the New Jersey Legislature emancipated in 1786 for his service in the Patriot army. In a letter he wrote to the Hunterdon County Court of Common Pleas, Prime bitterly stated how "I have not an equal right with white state subjects, as I cannot hold lands, sarve [sic] on jurys [sic], nor be a witness, nor sue for debt." Yet he was required to attend militia duty, which he accidentally missed and was assessed a fine. ${ }^{78}$ Even though the revised 1798 New Jersey slave code repealed the 1713 code, thereby permitting free blacks to own real estate, this would not have necessarily improved Prime's fortunes. For he still needed the requisite cash or credit to purchase land and the willingness of persons (principally white) to sell it to him. ${ }^{79}$

Servis and Kise, who were in-laws, may have decided that the honorable Compton was not deserving of such dishonorable treatment, and thus sold him land that adjoined theirs. ${ }^{80}$ Kise even helped to compile the inventory of Compton's will, suggesting that Kise was someone whom Compton knew and trusted. ${ }^{81}$ Compton's positive reputation among certain whites, along with his hard-earned prosperity, evidently opened the door of land ownership (prior to 1812) that otherwise

\footnotetext{
${ }^{77}$ For "home," see Cameron B. Blevins, “'Owned by Negro Venture': Land and Liberty in the Life of Venture Smith," in Venture Smith and the Business of Slavery and Freedom, Stewart, 153-54. For "place," see Richard S. Newman, Freedom's Prophet: Bishop Richard Allen, the AME Church, and the Black Founding Fathers (New York: New York University Press, 2008), 197.

${ }^{78}$ On Prime's war service and emancipation, see George Fishman, "Taking a Stand for Freedom in Revolutionary New Jersey: Prime's Petition of 1786," Science and Society 56, no. 3 (1992): 353-56. For the letter, see Petition of Negro Prime to the Honorable Court in Trenton (n.d.), NJSA.

${ }^{79}$ See Marion Thompson Wright, "New Jersey Laws and the Negro," Journal of Negro History 28, no. 2 (1943): 166; Hodges, Rural North, 125; and Hodges, Root and Branch, 176.

${ }^{80}$ On the family connection between Servis and Kise, see Arleen Melvin Smith, comp., "Descendants of Johnannes Servis (Zerbe) and Allied Lines," typescript (n.d.), 23, 25, Hunterdon County Historical Society, Flemington, NJ.

${ }^{81}$ Will and Inventory of Henry Compton, no. 2648.
} 
would have remained closed to him. This in turn led to other opportunities in his life, such as his building of Put's Tavern.

Compton pursued the chosen career path of many ex-Revolutionary War soldiers who were attracted to the status, income, and visibility of operating a public house. ${ }^{82}$ Owning his own business afforded him economic success and independence that was rare among free blacks in New Jersey at this time. ${ }^{83}$ As James Gigantino II has shown, this became far more possible for free black New Jerseyans in the 1830s, a condition resulting from natural increases in the black population and the influx of black manumissions owing to the state's gradual emancipation act of 1804 , that together created a greater black customer base for black-owned businesses. ${ }^{84}$ Compton's much earlier example of economic success and independence owes in part to the location of his (unlicensed) tavern. Cornelius Larison declares that, "surrounded by a virgin forest that extended for miles in every direction," the tavern was "far removed from the gaze of the law-abiding and the pious" (namely, the local officialdom that was reluctant to venture to such a remote and alien place). ${ }^{85}$ In this "virgin forest," Compton "managed his business, accumulated wealth, and became renowned." ${ }^{96}$ Here, Compton was without question his own master.

At Put's Tavern, Compton practiced an intriguing example of what one human geographer refers to as "inversion," whereby persons on the margin occupy the "center" and those in power assume the role of spectators. ${ }^{87}$ Once freed, Compton was often referred to as Harry Putnam, which he embraced. To highlight his elevated status on Sourland Mountain as a tavern owner, certain people shortened his adopted name of Harry Putnam to Harry Put, and his house became

\footnotetext{
${ }^{82}$ See Boyer, Old Inns and Taverns in West Jersey, 7-8.

${ }^{83}$ For other individual success stories, see Gigantino, Ragged Road, 76-77; and Hodges, Black New Jersey, 55-56.

${ }^{84}$ Gigantino, Ragged Road, 195-99. The details of the emancipation act are discussed in n. 103, below.

${ }^{85}$ Larison, Biografy, 30-31. See also Luce, Sourland Mountain, 55.

${ }^{86}$ Larison, Biografy, 28.

${ }^{87}$ David Sibley, Geographies of Exclusion: Society and Difference in the West (New York: Routledge, 1995$), 43-44$.
} 
commonly known as Put's Tavern. The surnames Putnam and Put drew inspiration from General Rufus Putnam, a key military officer during the Revolution. ${ }^{88}$ Compton embraced these surnames because they connoted power and respect. Harry Putnam or Put, a former bondman, stood before his white and black guests assuming center stage, representing a challenge to the established power relations that rendered black people as invisible and unimportant. ${ }^{89}$ To illustrate, in 1807 , New Jersey stripped free blacks of the vote, a right they had held since 1776; the franchise, as one scholar writes, was now limited to "free white male citizens of the state worth fifty pounds proclamation money. ${ }^{90}$ Despite his political exclusion as a free black man, the owner of Put's Tavern stood at the center of visibility and power.

Like William Johnson, the aforementioned free black barber of Mississippi, Compton believed that manhood involved a competitive public component. It is thus necessary to consider how performances of his prowess at Put's Tavern shined a spotlight on his occupation of the center. People frequented taverns in part to dance. According to a history of early New Jersey taverns, "natives from the neighborhood and the nearby Sourland Mountains would dance [at Woods Tavern] almost nightly, with occasional visitors from Trenton and other 'remote' places." ${ }^{91}$ Leslie Harris explains that the newly freed black men and women who frequented the dance halls in New York City at the turn of the nineteenth century executed complicated dance moves that drew the admiration of onlooking working-class whites, who attempted to emulate their skills. Newly freed blacks, Harris writes, "made their mark," or heightened their visibility, in the dance halls and on the docks, where they also publicly demonstrated their captivating dancing ability. ${ }^{92}$ Those African

\footnotetext{
${ }^{88}$ See Larison, Biografy, 28.

89 This insight draws on Timothy J. Brown, "Welcome to the Terrordome: Exploring the Contradictions of a Hip-Hop Black Masculinity," in Progressive Black Masculinities, ed. Athena D. Mutua (New York: Routledge, 2006$), 202$.

90 Wright, "New Jersey Laws," 173.

91 Van Hoesen, Early Taverns, 47.

${ }^{92}$ Leslie M. Harris, In the Shadow of Slavery: African Americans in New York City, 1626-1863 (Chicago: University of Chicago Press, 2003), 92. See also White, Somewhat More Independent, 179.
} 
Americans who came from rural Tappan, New Jersey, and Long Island, New York, to dance competitively at Catherine Market in Lower Manhattan in the late eighteenth and early nineteenth century (a scene of multiethnic economic and cultural exchange) beg our attention. W. T. Lhamon, Jr. explains that with their hair tied up in tea-lead or eelskins, or combed out like the fashionable wigs of the times, these young enslaved and free black performers - who danced for money or eels - assumed charismatic personalities that were desired by others. These proto-blackface performers executed their breakdown routines on their own "shingles," or dancing boards, rudimentary stages that facilitated another form of inversion. From this center position, Lhamon avers, the dancers presented their bodies as sites of agency and identity to fascinated whites, who congregated to absorb the dancers' grace and difference. At the same time that they pandered to white bigotry, popular dancers such as Bob Rowley, a Long Island bondman who went by the moniker "Bobolink Bob," were able to refigure their marginalized construction behind the mask that hid their pain. ${ }^{93}$

Dance, as it appears, played a similar role in Compton's life. His favorite dance steps, posits Silvia Dubois, were "the eleven times, twelve times, and thirteen times" - the same steps that she preferred. ${ }^{94}$ Her comment implies that Compton, like his enslaved and freed black compatriots who danced in New York City, performed complicated, physically demanding dance steps that reflected a general (black) cultural aesthetic of improvisation, physical vivaciousness, and polyrhythmic movement (meaning that different parts of the body express themselves simultaneously). ${ }^{95}$ As one who coveted the spotlight, it is difficult to imagine Compton not using dance as a means to refigure his marginality and, later, to maximize his visibility at his tavern.

\footnotetext{
${ }^{93}$ W. T. Lhamon, Jr., Raising Cain: Blackface Performance from Jim Crow to Hip Hop (Cambridge, MA: Harvard University Press, 1998), esp. 1-4, 7-16.

${ }^{94}$ Larison, Biografy, 94.

${ }^{95}$ See Shane White and Graham White, Stylin': African American Expressive Culture from Its Beginnings to the Zoot Suit (Ithaca, NY: Cornell University Press, 1998), 72-81.
} 
Compton invited the gaze, if not the desire, of spectators as he danced. How likely is it, then, that he failed to use his style of dance - an expression of his own identity - to help him occupy the center as a charismatic figure at Put's Tavern, and even beyond it in places such as Princeton?

And yet, Compton no longer needed to prove his worth and gain attention strictly through performances of his prowess. People change, and so did Compton. He now was, foremost, a "proprietor of a hotel, and a man of note as a mountain tavern keeper" - that is to say, a man of respectability. ${ }^{96}$ By respectability, Compton had, through his industry, frugality, and perseverance, "cultivated [his] inner character sufficiently to harvest the rewards of material success." 97 As a man of rugged respectability, his focus was more on improving his business rather than demonstrating his prowess.

Indeed, owing to its growing popularity, Compton eventually enlarged and, subsequently, rebuilt his house. According to legend, "the new house ... was somewhat pretentious. It consisted of four large rooms upon the first floor, and a half story, suitably divided into rooms, above. Along the entire front was a porch, and the windows and doors were ample."98 This expansion project brings to mind the business prowess of Samuel Fraunces, a well-known tavern keeper in New York City and Philadelphia. It would come as no surprise if Compton was partly inspired by the success of Fraunces, whose most noted venture was the Queen's Head Tavern in Lower Manhattan, a hotbed of Patriot activity. "Fraunces was a true entrepreneur, always trying to expand his own business activities and improve his personal fortunes," it has been emphasized; his "taverns were successful as places of public resort. He advertised that he entertained 'Gentlemen, Ladies and

\footnotetext{
${ }^{96}$ Larison, Biografy, 28.

${ }^{97}$ Patrick Rael, Black Identity and Black Protest in the Antebellum North (Chapel Hill: University of North Carolina Press, 2002), 131.

${ }^{98}$ Larison, Biografy, 30.
} 
others' in the "most genteel and convenient manner." 99 The enlarging and rebuilding of Put's Tavern reflected Compton's own business savvy and desire to "improve his personal fortunes." As a result, his "pretentious" establishment, which enhanced his occupation of the center as a man of some financial means, became "a popular place of resort" among sporting types who came from Trenton, Princeton, New Brunswick, New York, Philadelphia, and cities farther away. ${ }^{100}$

Compton's newly constructed abode played host to "cock fights, fox chases, hustling matches, prize fights," and other sporting activities. In his sporting world tucked away in the "virgin forest," like-minded people - lewd and intellectual white men, white women dressed in expensive and gaudy attire, mountain and city bandits, ragged blacks, the farmer-gambler donning his linsy-woolsy, the mechanic who sported satinette, the dandy, the drab - could meet and explore their common interests. Here, outcasts and renegades drank, gambled, conversed, used profane language, engaged in fights (even "white women and wenches" battled), sang indecent songs, and had illicit sex on relative terms of equality that, on the one hand, rejected the mores of the local officialdom and, on the other hand, emulated the defiant spirit of the Revolution, leveling racial and class distinctions. ${ }^{101}$

Correspondingly, Benjamin Carp argues that taverns took on particular importance during the Revolutionary era, transforming into staging grounds of cross-class political mobilization, without which coordinated resistance to British policy may not have been possible. It was in the taverns of New York City and throughout the eastern American seaboard, where the mob gathered to resist imperial encroachment, thereby setting the Revolution in motion. ${ }^{102}$ Compton's owning

\footnotetext{
${ }^{99}$ Kym S. Rice, Early American Taverns: For the Entertainment of Friends and Strangers (Chicago: Regnery Gateway or Fraunces Tavern Museum, New York, 1983), 125-30 (quotes on 128).

${ }^{100}$ Larison, Biografy, 30-31.

${ }^{101}$ Ibid., 28-32 ("cock fights, fox chases," on 28, "white women and wenches" on 32).

102 Benjamin L. Carp, Rebels Rising: Cities and the American Revolution (New York: Oxford University Press, 2007), chap. 2.
} 
of a tavern demonstrates his grasp - as a free black man - of traditional, pre-Revolutionary sources of power, while also enabling him to preside over a category of space symbolically linked to the Revolution's very beginnings and where the uprising could, in a sense, be continued. As a marginalized black man, he may have envisioned Put's Tavern not only as a space that lent him greater public visibility, but also where other forms of radical behavior could be experimented with, and under his control.

While occupying the center, Compton continued in his role as a committed family man. His 1813-1814 will provides a glimpse of this facet of his masculinity. In his will, Compton left \$14 to his daughter, Hannah, and "one new tow[el] and linen sheet" to Dorcas, who was married and still enslaved. Conversely, he left his entire estate first to his "loving wife," Jude, and then to his daughter, Rachel; and stipulated that his grandchildren Nancy, Benjamin, and Caleb pay either Jude or Rachel for their liberation. Nancy was required to pay \$15, whereas Benjamin and Caleb were both required to pay $\$ 25$ upon reaching the age of twenty-one. Compton's 1814 estate inventory valued the children, listed as his "slaves," as worth $\$ 65$, probably close to what he paid for them: in 1800, he paid Anne Acker $\$ 45$ for the children and their mother, Kate (apparently deceased by the time the will was written), and another $\$ 100$ four years later. ${ }^{103}$ These payments substantiate Compton's dedication to his family's liberation. In a way, so do the conditional term limits on the duration of his grandchildren's enslavement, which reduced the value of his estate; in other words, his estate would have had greater value if the children were "slaves" for life.

\footnotetext{
${ }^{103}$ Will and Inventory of Henry Compton, no. 2648; Harry Compton Deed of Purchase, 1803. By this information, Benjamin and Caleb were born between 1792 and 1800. Similarly, the New Jersey gradual emancipation act of 1804 stipulated that any enslaved child born after July 4 of that year would serve as an apprentice to its mother's owner until the child reached the age of twenty-five if male and age twenty-one if female. Hence, Compton liberated his grandchildren through terms associated with black oppression that appear to speak, in part, to his own concerns as a property owner. For discussion, see Wright, "New Jersey Laws," 171-78; Arthur Zilversmit, "Liberty and Property: New Jersey and the Abolition of Slavery," New Jersey History 88, no. 4 (1970): 215-16; Hodges, Rural North, 13536; Gigantino, Ragged Road, 65, 92-94, 97, 106-10; and Hendrik Hartog, The Trouble with Minna: A Case of Slavery and Emancipation in the Antebellum North (Chapel Hill: University of North Carolina Press, 2018), 50-52.
} 
Although we cannot ignore how the term limits appear to reflect Compton's concern as a landowner, we must also recognize that he placed securing the children's liberation over maximizing the value of his property. ${ }^{104}$

That said, requiring the children to pay for their freedom also hints at Compton's belief, shaped by his own self-purchase, that freedom was not free; not even his beloved grandchildren were exempt from the notion that freedom incurred a price that had to be paid. It would appear that, to the mind of this man of rugged respectability, this requirement benefitted the children as much as his estate that was entitled to their labor, because this showed that they were responsible persons who would not become burdens to society. The early 1700s saw free blacks in New Jersey stigmatized as "an idle, slothful people" who deserved their inferior status. ${ }^{105}$ Against the backdrop of this lingering racist sentiment, Compton agreed to "forever indemnify" Acker and her executors "from any trouble, cost, damage, or charges that may accrue" owing to the sale of his family. ${ }^{106}$ It was incumbent on him to safeguard his estate against any potential problems arising from the purchase; a logical assumption is that, in his will, he required the children to pay a kind of cheap liability insurance to his heirs, which also prepared the children for the responsibilities of freedom.

In his will, Compton's masculine identity has come full circle: from tough and seemingly angry bondman who coveted freedom in the households of others to respectable free man who decided his family's future in his own household. The writing of his will represents one of the final

\footnotetext{
${ }^{104}$ On term limits, see Hartog, The Trouble with Minna, 58-59.

${ }^{105}$ For racist sentiment, see Samuel Allinson, comp., Acts of the General Assembly of the Province of New-Jersey, from the Surrender of the Government to Queen Anne, on the 17 th Day of April, in the Year of Our Lord 1702, to the $14^{\text {th }}$ Day of January 1776 (Burlington, NJ: Isaac Collins, 1776), 20.

${ }^{106}$ Harry Compton Deed of Purchase, 1803. As an illustration of this lingering sentiment, in 1794, Theophile Cazenove (1740-1811), a Dutch business traveler, described free blacks in Morristown, New Jersey, as "quarrelsome, intemperate, lazy, and dishonest . . . are worse off than when they were slaves, although the race is open to them the same as to white people." Rayner Wickersham Kelsey, ed., Cazenove Journal, 1794: A Record of the Journey of Theophile Cazenove through New Jersey and Pennsylvania (Haverford: Pennsylvania History Press, 1922 ), 8.
} 
"acts" of his worth; it shows "a Coloured Man" putting his affairs in order. ${ }^{107}$ Interestingly, the term "colored" was widely used among black northerners as well as sympathetic whites by the 1830s, and was typically associated with respectability. ${ }^{108}$

Dubois maintains that following a prolonged absence from Compton's life, she went to visit him and he later asked her to stay and take care of the "old man." Hence, "at his death I inherited his property," she claims. ${ }^{109}$ Her recollection, however, does not square with Compton's will that, again, mentions Jude and then Rachel as the rightful heirs of his estate. How, then, did Dubois come to inherit the property?

It may be a case of the property literally falling into her hands. That is, over time, no one else in Compton's family was probably physically able to handle the rough-and-tumble types who frequented the tavern. This boisterous scene required the power and authority of someone such as Dubois. A common laborer with no real prospects of becoming a landowner, Dubois was more than happy to assume responsibility for what she termed "the old homestead." 110 The Biografy's heroine lived a life of economic independence only after she "inherited" the fruits of her grandfather's labors. Tragedy struck later on when, during an absence, persons unknown burned the tavern down in 1840. Undeterred, however, Dubois erected another home built of cedar and became a successful hog breeder. Then, while she was away in the 1870s, "those damned Democrats" (the party of slavery at the time), fumes Dubois, burned down her primitive home. Rendered homeless and penniless, the discouraged elderly woman went to live with her daughter, Elizabeth Alexander, in her rustic home near the top of Sourland Mountain. ${ }^{111}$

\footnotetext{
${ }^{107}$ Will and Inventory of Henry Compton, no. 2648.

${ }^{108}$ See Rael, Black Identity and Black Protest, 102.

${ }^{109}$ Larison, Biografy, 70.

${ }^{110}$ Ibid.

${ }^{111}$ Ibid., 33, 34-36, 70 (quote). On the hostile pro-slavery sentiment of white New Jerseyans, see Wright, "New Jersey Laws," 182-84.
} 
Thus ended the legacy of a black man who transformed throughout his life.

\section{Conclusion}

Located in the foreword and in scattered references in the main text of Silvia Dubois, A Biografy of the Slav Who Whipt Her Mistres and Gand Her Fredom is a forgotten yet powerful story about an enslaved and free black man who warrants our attention. Despite Cornelius Larison's conservative racial politics, the narrative allows us to discern how Harry Compton was a resilient and multidimensional figure who responded in intelligent and understandable ways to the world around him. As proposed herein, he perceived Richard Compton's hotel and tavern, military service, making charcoal, and Put's Tavern as critical public stages, whereby he demonstrated his worth as a man in varying ways. In doing so, he continually gave his life meaning, power, visibility, and in the end, historical significance. Rather than succumbing to the forces of racial oppression, he instead transformed throughout his life. To not transform, to remain static in his gendered identity, was to become victim "to man or set of men" (i.e., white male oppression).

The basis of Compton's evolving masculinity was, arguably, his “instinctive desire to be free." Indirectly, Larison suggests that Compton experienced visions, if not dreams, about freedom that strengthened his resolve to endure, and transform under, his degraded circumstances. Although he must have derived great satisfaction from his ability to put white and black men on the ground, which earned him public recognition, this feat alone could not bring his desire for freedom to fruition. Like so many other black men, Compton needed the Revolutionary War and the opportunity to serve on the Patriot side, the ultimate public stage to demonstrate his worth as a man. Presumably, with military service added to his masculine resume, he approached Richard Compton with an offer to purchase his freedom that the enslaver could not refuse. Indeed, Harry Compton's story speaks powerfully to how the power dynamics of northern slavery were hardly 
one-sided, that enslaved people possessed a degree of negotiating power that they wielded to improve their circumstances. That said, the privilege to purchase his freedom was not without risk; failure on this most public stage would send Compton back to the debasing institution of slavery, potentially tarnishing his legend of masculine prowess. The rewards, however, outweighed the risks as Compton, who now lived in "quasi freedom," worked, rested, and moved about on his own terms. As he made and sold charcoal, Compton shed his ignoble status as a commercial object and turned into a businessman; becoming his own master was now a distinct possibility. Small wonder, then, that once freed, Compton left rural Hillsborough Township, which stunted the lives of free blacks, and ended up in the vibrant (though racist) port town of New Brunswick, where he could perhaps more decisively throw off the yoke of bondage, and live his life more in accordance with his own goals and desires as a transforming man.

The evolution of Compton's masculinity culminated in the creation of secluded Put's Tavern, where he literally became "The Man" - that is, one who exercised authority over not only himself, but also over his family members and rowdy white and black patrons who accepted his occupation of the center. Even if, over time, his physical strength and fighting skills had diminished, his status was assured as a respectable and popular mountain tavern keeper. We can imagine, then, how Compton emerged as a hero among many free and enslaved blacks, who perceived his egalitarian tavern as a refuge from the weight of everyday oppressions, and who saw in him what they desired for themselves: power and respect. The fact that Compton gave a good account of himself as his own master tells us that he also made a lasting impression among whites, and not just Larison. Indeed, judging by both Larison and Silvia Dubois's opening comments to this article, few white people during Harry or Henry Compton's time would have failed to acknowledge him as tough, rugged, and transformative - and, therefore, as deserving of their 
respect. By the same token, Compton deserves our respect for serving as a compelling reminder of how African American men have historically moved about in US society with strength, vision, and determination - as if their black lives matter - despite the oppressive forces in their path.

A native of Trenton, New Jersey, Kenneth E. Marshall is Associate Professor of History at SUNY Oswego. He is the author of Manhood Enslaved: Bondmen in Eighteenth-and Early Nineteenth-Century New Jersey (University of Rochester Press, 2011), as well as multiple articles on the resistance, survival, and gendered lives of enslaved blacks in New Jersey. He is currently working on a book project that examines the life of Silvia Dubois. He wishes to thank archivist Bette Epstein for locating invaluable primary source materials on Harry Compton; Richard Weyhing, Susan Klepp, Meredith Roman, Graham Hodges, and the two anonymous reviewers for their helpful comments on drafts of this article; and NJS editor, Melissa Ziobro, for dealing with his constant revisions. 